\title{
ADAPTING TO CLIMATE CHANGE: WHO SHOULD PAY
}

\author{
DANIEL A. FARBER ${ }^{1}$
}

I. INTRODUCTION.............................................. 1

II. THE CHALLENGE OF ADAPTATION.............................. 4

$A$. The Reality of Climate Change............................ 4

B. Climate Change Impacts................................... 7

C. Adaptation Measures.................................... 16

III. WHO SHOULD PAY? ........................................ 18

A. Applicable Norms........................................ 19

1. Behavioral Goals...................................... 19

2. Loss-spreading......................................... 22

3. Just Deserts............................................. 23

4. Distributive and Social Goals.......................... 24

B. Four Possible Principles..................................... 26

C. Which Approach(es) to Favor? ............................ 34

IV. CONCLUSION..................................................... 36

\section{INTRODUCTION}

In Massachusetts v. EPA, ${ }^{2}$ the Supreme Court, for the first time, acknowledged the reality of climate change. The state of Massachusetts brought suit to challenge the Environmental Protection Agency's (EPA) refusal to limit carbon dioxide $\left(\mathrm{CO}_{2}\right)$ emissions from automobiles. ${ }^{3}$ To gain standing, the State had to demonstrate that it was injured by climate change. ${ }^{4}$ Central to its claim of injury was the allegation that sea level rise, caused by climate change, had already begun to eat away at its coastlines and would increasingly do so in the future. ${ }^{5}$ The State also cited the funds that it would be required to spend to ameliorate the im.

1. Sho Sato Professor of Law, University of California, Berkeley, Boalt Hall. An earlier version of this article was presented as Florida State University's Distinguished Lecture in Environmental Law in March 2007. I would like to thank Dave Markell and Evan Mills for their helpful comments in connection with this project, as well as members of the audience and other FSU faculty members who raised interesting issues at the lecture. This article is a companion piece to Daniel A. Farber, Basic Compensation for Victims of Climate Change, 155 U. PA. L. REv. 1605 (2007), which discusses some of the same issues but approaches them from a different angle. Further issues about compensation will be addressed in another forthcoming paper, Daniel A. Farber, Who's to Blame? Assigning Responsibility for Climate Change Impacts and Adaptation Costs, 26 UCLA J. ENVTL. L. \& POL'Y (forthcoming 2007).

2. 127 S. Ct. 1438 (2007).

3. Id. at 1446 .

4. See id. at 1446-47.

5. Id. at 1456 . 
pact of climate change. ${ }^{6}$ Because the state sought only regulatory action by the EPA, there was no occasion for the Court to consider the question of who should ultimately bear the costs of such climate change impacts. That cost-allocation issue is the subject of this Article.

As Justice Stevens' opinion for the Court recognized, climate change is already upon us. ${ }^{7}$ As most people now realize, we can no longer postpone serious consideration of how to respond to this threat. Most public attention has been focused on the issue of mitigation-that is, how to reduce greenhouse gas levels and by how much, so as to limit future increases in global temperatures. ${ }^{8}$ A less publicized, but also critically important topic, is the need to begin adapting to climate change. Adaptation is not going to be cheap. It is too early to make confident cost estimates, but the expense for the United States is clearly going to be in the billions of dollars annually for the next few decades. ${ }^{9}$

Adaptation has been a neglected topic, in part because mitigation seems more urgent, and in part for political reasons. The political reason is a fear by environmentalists that discussing possible adaptive measures might undermine the political pressure for mitigation. ${ }^{10}$ In my view, this is a mistake. As people learn more about the expense and difficulty of adaptation, they should become more interested in mitigation, not less so. In addition, regardless of mitigation, some climate change is already occurring and will continue to occur before mitigation measures can have any real impact. ${ }^{11}$ Thus, although adaptation may be less important than mitigation in the grand scheme of things, it is not something we can afford to ignore.

This Article addresses one subsidiary but important question: Who should absorb this cost? Several possible answers to the cost allocation question deserve exploration. We might leave it to the direct beneficiaries of adaptation projects to absorb the costs, or we might shift the costs to the entities that emitted greenhouse gases.

6. Id.

7. Id. at 1446 .

8. Nothing in this Article should be taken as detracting from the importance of implementing appropriate controls on greenhouse gases as soon as possible. Adaptation is not a substitute for mitigation-indeed, without mitigation, adaptation may cease to be achievable, and there will inevitably be harms, such as species extinction, that cannot be prevented through adaptation.

9. See infra text accompanying notes 76-80 for some cost estimates.

10. Amy Lynd Luers \& Susanne C. Moser, Cal. Climate Change Ctr., Preparing For the ImpaCts of Climate Change in CALIFornia: Opportunities and Constraints FOR ADAPTATION 9 (2006).

11. Id. at 2 . 
Alternatively, we might let taxpayers foot the bill or require regions that experience benefits from climate change to fund adaptation. Which alternative to prefer is not an easy question. The choice involves a complex mix of judgments about incentives and difficult normative issues regarding moral dessert and social solidarity.

The primary purpose of this Article is to explore these issues rather than advocate a solution. My tentative conclusion, however, is that "Emitters Pay" is the most attractive of the potential allocation principles, while "Climate Change Winners Pay" is the least compelling. Different types of adaptation at various times and places may be suited for different mixes of allocation principles.

Part II of this Article explores the challenges of adaptation. After addressing lingering doubts about the reality of humancaused climate change, Part II surveys the negative effects of climate change. Thinking about adaptation has not advanced as far as thinking about mitigation of climate change (a/k/a prevention), but it is already clear that billions of dollars will be involved.

Part III turns to the question of cost allocation. I will begin by teasing out some of the relevant social goals. I will then consider four possible cost allocation principles: "Beneficiaries Pay," "Emitters Pay," "Public Pays," and "Winners Pay." These principles do not cover the universe of possibilities, but they seem to be the most plausible and provide more than enough complications for now. Part III suggests that the preferred principle should be "Emitters Pay" but that cost allocations between taxpayers and beneficiaries ("Public Pays" plus "Beneficiaries Pay") may also have a role.

The Article closes in Part IV with some thoughts about the climate change debate and prospects for a reasonable cost allocation scheme. Where politics are concerned, predictions are always hazardous, and the idealist is apt to look silly in retrospect.

Why care about allocation? Isn't mitigation more important than adaptation? And isn't what we order for dinner at the Climate Response Café a lot more important than who pays the tab? As to the first question, what we do in terms of mitigation will have a greater impact on future generations. Yet infrastructure decisions made today may still be important decades from now, and how we adapt will have more direct effect in the near term than mitigation efforts. In short, mitigation is critical to the welfare of later generations, while adaptation is critical to our own generation and that of our children.

As to the second question, who pays the tab may be very important. Certainly, it should be regarded as important by lawyers, 
who are often in the position of arguing about financial responsibility after the fact. It is also important because choosing the wrong cost allocation scheme for adaptation might undermine mitigation efforts by diverting needed funding to adaptation projects, or it might lead to investment in ill-advised adaptation projects. Allocating adaptation costs is also important to the extent that we believe moral as well as practical issues are involved in determining responsibility for climate change impacts. Finally, a sound cost allocation system may make it easier to overcome the collective action problems involved in climate change adaptation, such as the risk of rent-seeking by beneficiaries of adaptation. If at least a default rule can be established for payment for adaptation, negotiations on which adaptation measures to adopt will be simplified.

Most importantly, we should start thinking about cost allocation now because very soon the world is going to start doing so. As the realization sinks in that climate change will cause billions of dollars of harm even if we do everything feasible to cut back on emissions, the people who are directly harmed are going to start wondering whether they alone should bear the costs. It behooves us as scholars and lawyers to begin thinking through the issues before they reach the front pages of the newspaper.

\section{The Challenge of AdAPtation}

We begin with some basic questions: Is climate change real? Will it have serious effects? Will it be expensive to cope with those effects after they transpire? As we will see, the answer to all three questions is the same-yes.

\section{A. The Reality of Climate Change}

How sure can we be that climate change is a genuine threat? The most reliable source is the Intergovernmental Panel on Climate Change's (IPCC) 2007 report, which explains the scientific consensus that:

Global atmospheric concentrations of carbon dioxide, methane and nitrous oxide have increased markedly as a result of human activities since 1750 and now far exceed pre-industrial values determined from ice cores spanning many thousands of years. The global increases in carbon dioxide concentration are due primarily to fossil fuel use and land-use 
change, while those of methane and nitrous oxide are primarily due to agriculture..$^{12}$

If this report is wrong, it is not for lack of adequate discussion and feedback. The IPCC report is the result of an exhaustive review process:

Forty governments nominated the 150 lead authors and 450 contributing authors of Climate Change 2007: The Physical Science Basis. . . . Authors had their draft chapters reviewed by all comers. More than 600 volunteered, submitting 30,000 comments. Authors responded to every comment, and reviewers certified each response. With their final draft of the science in hand, authors gathered in Paris, France, with 300 representatives of 113 nations for 4 days to hash out the wording of a scientist-written Summary for Policymakers. ${ }^{13}$

Because of improvements in modeling and data, the $2007 \mathrm{Re}-$ port was able to eliminate some concerns previously raised about climate change. In particular, four key issues were resolved:

- The "urban heat island effect," caused by the tendency of urban concrete and asphalt to absorb heat, is real, but "a negligible influence" on overall temperature.

- The previous discrepancy between earth-based and satellite-based temperature measurements has been resolved by improved satellite measurements, which are more in line with the earthbased results.

12. Intergovernmental Panel on Climate Change, Climate Change 2007: The PHYSICAL SCIENCE BASIS: SUMMARY FOR POLICYMAKERS: CONTRIBUTION OF WORKING GROUP I TO THE FOURTH ASSESSMENT 2 (2007) [hereinafter IPCC] (citations omitted). The IPCC explains that " $[\mathrm{t}] \mathrm{he}$ understanding of anthropogenic warming and cooling influences on climate has improved since the Third Assessment Report (TAR), leading to very high confidence that the globally averaged net effect of human activities since 1750 has been one of warming, with a radiative forcing of $+1.6[+0.6$ to +2.4$] \mathrm{W} \mathrm{m}-2$." Id. at 5 (alteration in original) (footnote omitted).

13. Richard A. Kerr, Scientists Tell Policymakers We're All Warming the World, 315 SCI. 754, $754(2007)$. 
- Natural forces such as volcanoes and variations in solar intensity can influence climate and have done so in the past, but these natural variations could not produce the currently observed patterns of climate change.

- Evidence shows that the climate system is sufficiently sensitive to atmospheric composition to produce the observed climate change, as shown by the response to other disturbances such as the Mount Pinatubo eruption of $1991 .{ }^{14}$

Of course, complete scientific certainty is never possible, and the IPCC claims only that its conclusions are highly likely (over $90 \%){ }^{15}$ But social policy can never be based on complete certainty. The current evidence on climate change is the result of an intensive, international scientific effort. The IPCC process is imperfect but a good representation of the current state of the science; ${ }^{16}$ if anything, the process tends to underplay risks. ${ }^{17}$ To demand complete certainty is quixotic: governments, firms, and individuals have to make the best decisions they can today on the basis of

14. Id. at 755 .

15. Id. at 754 .

16. As the New York Times recently explained:

The panel, which has tracked research on global warming since it was created under United Nations auspices in 1988, has sometimes been criticized for allowing governments to shape the summaries of its periodic reviews of climate science.

But by many accounts, it remains the closest thing to a barometer for tracking the level of scientific understanding of the causes and consequences of global warming.

James Kanter \& Andrew C. Revkin, Scientists Detail Climate Changes, Poles to Tropics, N.Y. TIMES, Apr. 7, 2007, at A6.

17. For example, political leaders insisted on weakening language about the stringency of climate change impacts in the most recent IPCC report:

The meeting here dragged on in a marathon session Thursday night before Dr. Pachauri emerged midmorning on Friday and stood on a blue armchair in front of reporters to announce that agreement had been reached between scientists and government officials over the final details of a 21-page summary.

Under pressure from nations including Russia, China and Saudi Arabia, the authors said, sections on coral damage and tropical storms were softened in the summary. They also got the authors to drop parts of an illustration showing how different emissions policies might limit damage. Officials from those countries argued that data in the report did not support the level of certainty expressed in the final draft.

But some authors were not assuaged. The final document was "much less quantified and much vaguer and much less striking than it could have been," said Stéphane Hallegatte, a participant from France's International Center for Research on the Environment and Development.Id. 
available information. ${ }^{18}$

In considering loss allocation, we should keep in mind that our legal system has never demanded anything close to certainty as a basis for shifting losses. The plaintiff in an ordinary tort case need only prove by a preponderance of evidence that the defendant bears responsibility for the loss. Thus, even the common law requires only a showing that reallocation is justified "more likely than not." In terms of the existence of climate change and the linkage to human activity, we seem to be well past that point today. Even those who are skeptical of the need to mitigate greenhouse gases should be willing to accept that adaptation measures are a reasonable precaution, and this inescapably raises the question of who should pay the resulting costs.

\section{B. Climate Change Impacts}

The question of mitigation is beyond the scope of this Article. Mitigation may affect the degree of adaptation that is ultimately required, but in the short run it will have little effect. The reality is that, whatever mitigation measures are adopted, a significant degree of climate change seems unavoidable. ${ }^{19}$ As the IPCC ex-

18. Some of those decisions will necessarily involve investments now in infrastructure, some of which might turn out to be unnecessary if the climate change problem turns out to be less serious than we now believe. If we shift those costs to emitters or beneficiaries of adaptation, and the costs later turn out to be unnecessary, would we have committed an injustice? In my opinion the answer is no. Risks create real costs even when the risk does not materialize, and rules reallocating those costs do not retroactively become unjust when the existence of the risk is disproved. Suppose a person is in an accident due to a tortfeasor's negligence. If a doctor gives a precautionary tetanus shot, he can charge for the service. In turn, the victim can sue the tortfeasor for the expense. Suppose we later learn that the victim was not in fact exposed to any tetanus bacilli. That discovery surely would not be a basis for refund from the tortfeasor to the victim or from the victim to the tortfeasor.

19. As described in Donald A. Brown, The U.S. Performance in AchievingIts 1992 Earth Summit Global Warming Commitments, 32 ENVTL. L. REP. 10741, 10756 (2002):

Many scientists and policy makers believe that a doubling of $\mathrm{CO} 2$ from pre-industrial levels to $560 \mathrm{ppm}$ may be unavoidable in [the] $21 \mathrm{st}$ century. This is so because the world's political and economic system cannot respond rapidly enough to make faster changes in some major polluting sources such as gasoline-powered automobiles or coal-fired power plants. Some environmentalists, however, believe it is still possible to stabilize GHG at $450 \mathrm{ppm}$, a level that would limit the temperature increase (in addition to that which has already been caused by human activities) to 1.5 to 2 degrees $F$ [ ] during the next 100 years. Virtually nobody believes that it is possible to stabilize atmospheric concen. trations below $450 \mathrm{ppm}$ and concentrations could continue growing after that if third world countries do not implement aggressive reduction strategies, even if the most ambitious proposal currently under consideration were adopted. Even if all nations could have stabilized emissions in the year 2002, the concentrations of GHGs would continue to rise and would approach $500 \mathrm{ppm}$ by the year 2100 . After that, GHG concentra- 
plains, "[a]nthropogenic warming and sea level rise would continue for centuries due to the timescales associated with climate processes and feedbacks, even if greenhouse gas concentrations were to be stabilized."20

The best current estimate is that a doubling of $\mathrm{CO}_{2}$ from preindustrial levels would result in a temperature increase between $1.5^{\circ} \mathrm{C}$ and $4.5^{\circ} \mathrm{C}\left(1.8\right.$ to $\left.5.4^{\circ} \mathrm{F}\right)$ by the end of this century. ${ }^{21}$ For this reason, even in the best-case scenario, we will be faced with a number of adverse impacts from climate change. Indeed, we may already be experiencing them.

Examples of observed changes caused by human releases of GHG include shrinkage of glaciers, thawing of permafrost, later freezing and earlier break-up of ice on rivers and lakes, lengthening of mid-to highlatitude growing seasons, poleward and altitudinal shifts of plants and animal ranges, declines of some plant and animal populations, and earlier flowering of trees, emerging of insects, and egg-laying in birds. ${ }^{22}$

Climate changes will cause net global losses, but losses will not fall evenly everywhere in the world. A postscript to the Stern report points out that "[a]t $1-2^{\circ} \mathrm{C}$ of temperature rise, there will be some winners and some losers. Longer growing seasons in northern latitudes, and reduced mortality from winter cold snaps, will create economic gains in some areas and opportunities for new activities including in the agriculture, energy and tourism sectors in some regions." ${ }^{23}$ Cass Sunstein reports estimates that a $2.5^{\circ} \mathrm{C}$ increase could cost India almost 5\% of GDP but China only about (footnotes omitted).

tions in the atmosphere would continue to rise for several hundred years before stabilization would be achieved. Even to stabilize $\mathrm{CO} 2$ at 1,000 ppm will require reductions of emissions below current levels.

20. IPCC, supra note 12 , at 17.

21. See Richard A. Kerr, Latest Forecast: Stand By for a Warmer, But Not Scorching, World, 312 ScI. 351 (2006). For an up-to-date source of information on climate science, see RealClimate Home Page, http://www.realclimate.org (last visited Nov. 18, 2007).

22. Brown, supra note 17, at 10756 (footnotes omitted). For further details on climate change effects in the United States, see Camille Parmesan \& Hector Galbraith, Pew Ctr. on Global Climate Change, Observed Impacts of Global Climate Change in THE U.S. 1 (2004), available at http://www.pewclimate.org/docUploads/final_ObsImpact.pdf.

23. After the Stern Review: Reflections and Responses: Paper A: The Case for Action to Reduce the Risks of Climate Change 6 (Feb. 12, 2007) (unpublished paper, on file with the Stern Review), available at http://www.hm-treasury.gov.uk/media/9/C/stern_yalea 091107.pdf. 
$.2 \%{ }^{24}$ Africa would lose almost $4 \%$, which is particularly alarming given the region's current economic situation. ${ }^{25}$

Sea level rise is one of the most predictable consequences of climate change. ${ }^{26}$ Apart from the unknown contribution of melting from Greenland and Antarctica, ${ }^{27}$ the simple change in temperature of the oceans will contribute to thermal expansion, just as increased temperature causes the mercury in a thermometer to rise. ${ }^{28}$ As the IPCC explains, "[o]bservations since 1961 show that the average temperature of the global ocean has increased to depths of at least $3000 \mathrm{~m}$ and that the ocean has been absorbing more than $80 \%$ of the heat added to the climate system. Such warming causes seawater to expand, contributing to sea level rise." 29 Moreover, the IPCC reports that "[m]ountain glaciers and snow cover have declined on average in both hemispheres. Widespread decreases in glaciers and ice caps have contributed to sea level rise (ice caps do not include contributions from the Greenland and Antarctic ice sheets)." 30 Sea level rise is at the opposite end of the scale from being speculative. ${ }^{31}$

24. Cass R. Sunstein, Of Montreal and Kyoto: A Tale of Two Protocols, 31 HARV. ENVTL. L. REV. 1, 48 fig. 7 (2007).

25. Id.

26. See, e.g., K. Hasselman et al., The Challenge of Long.Term Climate Change, 302 SCI. 1923, 1924 fig.1 (2003) (predicting a two meter increase in sea level under a "businessas-usual" scenario by 2100 , but only twenty centimeters under an optimum regulatory strategy). The effects of seal level rise are discussed in more detail in Susanne C. Moser, Climate Change and Sea-Level Rise in Maine and Hawai'i: The Changing Tides of an Issue Domain 201, in Global ENVIRONMENTAL Assessments (Ronald B. Mitchell et al. eds., 2006).

27. On the potential for catastrophic melting in these areas, see NicHOLAS STERN, The Economics of Climate Change: The Stern Review 20 box 1.4 (2007). The IPCC reports simply that "[d]ynamical processes related to ice flow not included in current models but suggested by recent observations could increase the vulnerability of the ice sheets to warming, increasing future sea level rise. Understanding of these processes is limited and there is no consensus on their magnitude." IPCC, supra note 11 , at 17 . However, the IPCC also reports that uncontrolled warming could have dramatic consequences:

Contraction of the Greenland ice sheet is projected to continue to contribute to sea level rise after 2100 . Current models suggest ice mass losses increase with temperature more rapidly than gains due to precipitation and that the surface mass balance becomes negative at a global average warming (relative to pre-industrial values) in excess of 1.9 to $4.6^{\circ} \mathrm{C}$. If a negative surface mass balance were sustained for millennia, that would lead to virtually complete elimination of the Greenland ice sheet and a resulting contribution to sea level rise of about $7 \mathrm{~m}$. The corresponding future temperatures in Greenland are comparable to those inferred for the last interglacial period 125,000 years ago, when paleoclimatic information suggests reductions of polar land ice extent and 4 to $6 \mathrm{~m}$ of sea level rise. Id.

28. Changes in ocean temperature will also affect fish stocks. See Hans O. Pörtner \& Rainer Knust, Climate Change Affects Marine Fishes Through the Oxygen Limitation of Thermal Toleration, 315 SCI. 95 (2007).

29. IPCC, supra note 12 , at 7 (citation omitted).

30. Id.

31. For more scientific background on the issue, see Stefan Rahmstorf, $A$ SemiEmpirical Approach to Projecting Future Sea-Level Rise, 315 SCI. 368 (2007); Andrew Shepherd \& Duncan Wingham, Recent Sea-Level Contributions of the Antarctic and Greenland Ice Sheets, 315 SCI. 1529 (2007). 
This rise in sea level will result in loss of coastal lands, ${ }^{32}$ inundation of some estuary systems with salt water, salt water intrusions into some drinking sources, and increased exposure to flood damage. $^{33}$ Sea level change may have drastic effects on island populations. ${ }^{34}$ For example, the small island state of Tuvalu is seeking ways to evacuate its entire population. ${ }^{35}$

Sea level rise could also cause dramatic losses in the wetlands in the United States. ${ }^{36}$ Because the slope of coastal areas on the Atlantic and Gulf Coasts is low, a forty centimeter rise in sea level could result in as much as sixty meters of beach erosion and cost in the billions of dollars. ${ }^{37}$ As I discuss later, this emphatically applies to Florida To get a sense of the potential economic impact, consider the following estimates regarding sea level rise: A halfmeter sea level rise would place $\$ 185$ billion of property in jeopardy by 2100 , and the cost of protecting developed areas from a half-meter rise would be $\$ 50$ to $\$ 66$ billion. ${ }^{38}$

Summarizing the most recent data, the IPCC's Fourth Assessment says:

Coasts are projected to be exposed to increasing risks, including coastal erosion, due to climate change and sea-level rise and the effect will be exacerbated by increasing human-induced pressures on coastal areas.

Corals are vulnerable to thermal stress and have low adaptive capacity. Increases in sea surface temperature of about 1 to $3^{\circ} \mathrm{C}$ are projected to result in more frequent coral bleaching events and widespread

32. See A. Barrie Pittock, Climate Change: Turning Up the Heat 262-82 (2005) for examples, including China, India, Pakistan, Bangladesh, and the United States.

33. See Elizabeth KolBert, Field Notes From a Catastrophe: Man, NATURe, and Climate CHANGe 123-24 (2006) (reporting that what are now hundred-year floods could become routine by late in this century) see also PITTOCK, supra note 32 , at 118 box 5 (stating that without adaptive measures, annual flood losses would increase from $£ 1$ to 27 billion in different scenarios).

34. See Denis Culley, Comment, Global Warming, Sea Level Rise and Tort, 8 OCEAN \& CoASTAL L.J. 91, 105-07 (2002).

35. Id. at $92-93,106$.

36. Id. at 100 .

37. David A. Grossman, Warming up to a Not-So-Radical Idea: Tort-Based Climate Change Litigation, 28 COLUM. J. ENVTL. L. 1, 12-14. (2003).

38. William E. Easterling III et al., Pew Ctr. on Global Climate Change, Coping with Global Climate Change: The Role of adaptation in the Untted States 14 (2004), available at $\mathrm{http}: / \mathrm{www}$.pewclimate.org/docUploads/Adaptation.pdf. This estimate may be on the high side, but even if we discount by a factor of two, the figures are still impressive. 
mortality, unless there is thermal adaptation or acclimatisation by corals.

Coastal wetlands including salt marshes and mangroves are projected to be negatively affected by sealevel rise especially where they are constrained on their landward side, or starved of sediment.

Many millions more people are projected to be flooded every year due to sea-level rise by the 2080 s. Those densely-populated and low-lying areas where adaptive capacity is relatively low, and which already face other challenges such as tropical storms or local coastal subsidence, are especially at risk. The numbers affected will be largest in the megadeltas of Asia and Africa while small islands are especially vulnerable. ${ }^{39}$

The IPCC assessment also notes that in North America,

[c]oastal communities and habitats will be increasingly stressed by climate change impacts interacting with development and pollution. Population growth and the rising value of infrastructure in coastal areas increase vulnerability to climate variability and future climate change, with losses projected to increase if the intensity of tropical storms increases. Current adaptation is uneven and readiness for increased exposure is low. ${ }^{40}$

Increased ocean temperatures lead not only to sea level rise but also to an increased risk of damage from storms. Stern explains the connection:

Infrastructure damage costs will increase substantially from even small increases in sea temperatures because: (1) peak wind speeds of tropical storms are a strongly exponential function of temperature, increasing by about $15-20 \%$ for a $3^{\circ} \mathrm{C}$ increase in

39. Intergovernmental Panel on Climate Change, Climate Change 2007: CliMate Change IMPACTS, ADAPTATION AND VULNERABILITY: SUMmaRY FOR POLICYMaKERS: WORKING GROUP II CONTRIBUTION TO THE IPCC FOURTH ASSESSMENT REPORT 9 (2007) [hereinafter IPCC Adaptation Report] (citations omitted).

40. Id. at 13 . 
tropical sea surface temperatures; and (2) damage costs typically scale as the cube of wind-speed or more. Storms and associated flooding are already the most costly natural disaster today, making up almost $90 \%$ of the total losses from natural catastrophes in 2005 ( $\$ 184$ billion from windstorms alone, particularly hurricanes and typhoons). A large proportion of the financial losses fall in the developed world, because of the high value and large amount of infrastructure at risk..$^{41}$

The IPCC agrees that "[i]t is very likely that hot extremes, heat waves, and heavy precipitation events will continue to become more frequent." 42 The IPCC also concurs that we are likely to see changes in tropical storms such as hurricanes:

Based on a range of models, it is likely that future tropical cyclones (typhoons and hurricanes) will become more intense, with larger peak wind speeds and more heavy precipitation associated with ongoing increases of tropical SSTs. There is less confidence in projections of a global decrease in numbers of tropical cyclones. The apparent increase in the proportion of very intense storms since 1970 in some regions is much larger than simulated by current models for that period.

Extra-tropical storm tracks are projected to move poleward, with consequent changes in wind, precipitation, and temperature patterns, continuing the broad pattern of observed trends over the last halfcentury. ${ }^{43}$

According to the Stern Report, "[c]hanges in rainfall patterns and extreme weather events will lead to more severe impacts on people than that caused by warming alone." 44 There are strong indications that climate change may lead to much more severe droughts in some regions. ${ }^{45}$ The IPCC confirms that

41. STERN, supra note 27, at $92-93$ (footnotes omitted).

42. IPCC, supra note 12 , at 16 .

43. Id.

44. STERN, supra note 27 , at 17 .

45. See Kolbert, supra note 33, at 108-18; Carl T. Hall, Global Warming Study Forecasts More Water Shortages: Climate Change Already Affecting Sierra Snowpack, SAN Francisco Chron., Nov. 17, 2005, at A4; Richard M. Adams \& Dannele E. Peck, Drought And Climate Change: Implications for The West 1 (Dec. 2002) (unpublished manuscript, on 
[1]ong-term trends from 1900 to 2005 have been observed in precipitation amount over many large regions. Significantly increased precipitation has been observed in eastern parts of North and South America, northern Europe and northern and central Asia. Drying has been observed in the Sahel, the Mediterranean, southern Africa and parts of southern Asia. ${ }^{46}$

Many areas rely on single-source water systems that are "extremely sensitive" to climate. ${ }^{47}$ Severe stress on water supplies is also a possibility in some parts of the world, such as Africa and the Middle East, ${ }^{48}$ as well as Australia. ${ }^{49}$ In California, the state water agency is devoting major attention to the impact of climate change on the state's water supply. ${ }^{50}$ Increases in flooding are also likely to be significant in some areas. ${ }^{51}$ It may be difficult to tie any one year of drought or a particular flood to climate change, but dealing with these threats will clearly involve significant challenges.

Some natural systems react particularly strongly to temperature changes. ${ }^{52}$ There is considerable evidence that coral reefs have been adversely affected by climate change. ${ }^{53}$ The Florida connection will be addressed later. At the other climatic extreme, glaciers and areas of tundra are being heavily impacted. Almost a quarter of the land in the Northern Hemisphere is situated on permafrost, much of which seems to be melting rapidly. ${ }^{54}$ Arctic

file with the Or. State Univ. Dep't of Agric. \& Res. Econs.), available at http://www.economics.noaa.gov/library/documents/benefits_of_weather_and_climate_forecas ts/drought-climate_change-implications_for_west.doc; Michael McCarthy, The Century of Drought, INDEP. (U.K.), Oct. 4, 2006, available at http://environment.independent.co.uk/ article1786829.ece.

46. IPCC, supra note 12 , at 8 (footnote omitted).

47. Kenneth D. Frederick, Water Resources and Climate Change, in Climate CHANGE ECONOMICS AND PoLICY 67, 68-69 (Michael A. Toman ed., 2001).

48. Pittock, supra note 32, at 253-54. Note also that "[p]otential increases in the frequency and intensity of drought across subhumid Africa are likely to increase desertification." Id. at 255.

49. Id. at 257. China may be vulnerable to drought increases as well. Id. at 263 .

50. See California Department of Water Resources, Climate Change in California (2007), available at http://www.water.ca.gov/climatechange/docs/062807factsheet.pdf.

51. For the most up to date information on how climate change will affect severe weather events, see http://www.ncdc.noaa.gov/oa/climate/research/ monitoring.html (last visited Dec. 8, 2007).

52. In addition to the items discussed here, increases in wildfires may be another, similar form of damage. See A.L. Westerling et al., Warming and Earlier Spring Increase Western U.S. Forest Wildfire Activity, 313 ScI. 940 (2006).

53. See Culley, supra note 34 , at 95 .

54. Kolbert, supra note 33 , at $13 \cdot 15$. Some of these changes may be augmented by 
Sea ice is also shrinking at a surprising rate. ${ }^{55}$

What does this mean for Florida? Permafrost is not the problem, to say the least. But Florida is nonetheless vulnerable. A recent report from the Florida Center for Environmental Studies explains that "[a]ll of Florida will be impacted by sea level rise, changes in hurricane frequency and intensity, changes in the intensity of flood and drought, and temperature increase," with ripple effects on "flora and fauna, agriculture, economy, and lifestyle." 56 North Florida has a very flat coastal area and water allocation issues with neighboring states that may be intensified by stream flow changes. ${ }^{57}$ Central Florida's agriculture and tourism may be impacted, and hurricane threats to Tampa and elsewhere are a concern..$^{58}$ South Florida may be particularly vulnerable, facing threats to freshwater aquifers, changes in coastal areas, and impacts on the Everglades. ${ }^{59}$ In addition, the impact on Florida's coral reefs is obviously a concern..$^{60}$

In the really long run, sea-level change may be the biggest threat to Florida. From the Jurassic Era, when dinosaurs still walked the earth, until the last interglacial melt, South Florida was generally sea bottom. ${ }^{61}$ It is not hard to imagine that the situation might revert in future centuries to the geologically "normal," with Miami taking the place of Atlantis in mythology. Less dramatically but still seriously enough, much of Florida may someday find itself repeating the fate of the Louisiana coast. ${ }^{62}$

climate fluctuations rather than long-term trends. See Richard A. Kerr, Could Mother Nature Give the Warming Arctic a Reprieve?, 315 ScI. 36 (2007) (reporting that current warming trends may in part reflect natural variability rather than long-term warming).

55. Kolbert, supra note 33 , at 25 .

56. Fla. CTR. For EnVtl. Studies, Practical Issues Related to Climate Change IN FLORIDA: A WORKSHOP ON NEEDS ASSESSMENT AND RESPONSES: SUMMARY REPORT 5 (2006), available at http://www.ces.fau.edw/ccc/FL_CLIMATE_CHANGE.pdf.

57. Id. at 5-6.

58. Id. at 6 .

59. Id. at 7 .

60. The National Wildlife Federation (NWF) maintains that:

As much as 90 percent of the region's coral reefs are dead or dying due to a host of factors, including global warming. An increase in average sea temperatures over the past 30 years has caused widespread coral bleaching, where corals lose the colorful algae in their tissues that they need to survive.

Nat'l Wildlife Fed'n, Global Warming and Florida 1 (2007), available at http://111.nwf.org/ globalwarming/pdf/Florida.pdf. The NWF also reports that habitat and wildlife losses could have a significant economic impact, since almost five million people spent around six billion dollars annually on wildlife-related activities in Florida. Id. at 2.

61. Michael Grunwald, The Swamp: The Everglades, Florida, AND the Politics OF PARADISE 15 (2006).

62. Consider the account of a visitor to a Cajun community:

I can almost hear the Gulf breakers just beyond sight, getting closer and closer, washing away more land every second, every minute, every hour, fifty acres every day. 
Short of such long-term disaster scenarios, there is still plenty of reason to worry about sea level change.

The Century Commission for a Sustainable Florida, in its first annual report to the Governor and the Legislature this year, summarizes some of the expected impacts of warming on Florida. ${ }^{63}$ The Commission estimates that a thirty inch increase in sea levels over the next century would translate into a four hundred foot inward move of the shoreline, with serious effects on the state. ${ }^{64}$ About a third of the state's ocean beaches and two-thirds of its estuarine beaches could disappear, and the lower Everglades could be completely drowned. ${ }^{65}$ In turn, salt water intrusions into the Everglades will contaminate the Biscayne aquifer, a key water source for all of south Florida. ${ }^{66}$ Coastal cities will face huge costs because of flood risks. ${ }^{67}$ Given that about fifteen out of every sixteen Floridians lives within thirty-five miles of the coast, ${ }^{68}$ sea level rise and increased hurricane surges are obviously a major concern for most of the population. Unfortunately, Floridians are moving to the coast in ever greater numbers, placing themselves and their property at risk. ${ }^{69}$

Over the long run, mitigation is the key to getting these impacts under control. But in the short run, sea level rise seems nearly inevitable, along with other climate-driven changes affecting Florida and other places. What we cannot prevent through

"I'm a fisherman, me, like my daddy and granddaddy," Wayne [a Cajun] tells me. "But de marsh, he's killin' us. He just won't hold togedder anymore. We'll all be leavin' here soon, just like de ducks in de spring, everybody moving on."

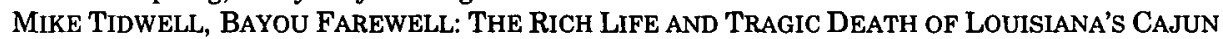
COAST 7 (2003). When he returned less than a year later to Louisiana, Tidwell could already see changes:

On the drive into town that morning I passed the Leeville cemetery, the one by the bridge, and was startled to see only eight crypts still visible above the water. By my count, the crumbling remains of at least four tombs, all barely above water when I visited here the year before, were now gone. Completely submerged. With just ten months separating my two visits, I'm already a veteran witness of Louisiana land loss, equipped with my own startling anecdote to tell: "Why, I remember when a full quarter of the Leeville cemetery was still above water and you could see..." Id. at 82-83.

63. Century Comm'n for a Sustainable Fla., First AnNual Report to the GovERNOR AND THE LEGISLATURE 3 (2007).

64. Id. at 62 . Even a fifteen inch increase would inundate half of the state's salt marshes and over three-quarters of its tidal flat. Id. at 64.

65. Id. at 62 .

66. Id. at 63 .

67. Id. at 62 .

68. Id.

69. A dramatic illustration is found in a graph of coastal population over time in Stephen LeATHERMAN, INT'L HURRICANE RESEARCH CTR., SEA LEVEL RISE AND CoASTAL IMPACTS 37 (2007), available at http://www.floridaclimatechange.com/images/Stephen LeathermanSeaLevelRise.pdf. 
mitigation, we must try to adapt to as well as we can.

\section{Adaptation Measures}

Adaptation has not received nearly as much attention as mitigation, but we can already begin to see the outlines of adaptation needs. Of course, the scale of adaptation needed is related to the degree of mitigation: if we do nothing to limit emissions, climate change will be more drastic and the costs of adaptation will be correspondingly higher. The IPCC notes that adaptation covers a wide spectrum of responses:

The array of potential adaptive responses available to human societies is very large, ranging from purely technological (e.g., sea defences), through behavioural (e.g., altered food and recreational choices) to managerial (e.g., altered farm practices), to policy (e.g., planning regulations). While most technologies and strategies are known and developed in some countries, the assessed literature does not indicate how effective various options are to fully reduce risks, particularly at higher levels of warming and related impacts, and for vulnerable groups. In addition, there are formidable environmental, economic, informational, social, attitudinal and behavioural barriers to implementation of adaptation. For developing countries, availability of resources and building adaptive capacity are particularly important. ${ }^{70}$

Few of these measures are costless, and some may turn out to be quite expensive.

The Pew Foundation collected much of the available information about adaptation strategies in a 2004 report. ${ }^{71}$ One conclusion is that we will need to develop new agricultural plant varieties to deal with changing temperatures, rainfall, and pests. Since 1980, federal expenditures for agricultural research have been flat, ${ }^{72}$ but substantial increases will probably now be needed. Farmers will have to make risky decisions about when the climate has changed enough to justify switching to new varieties and growing methods. ${ }^{73}$ Agricultural production is likely to shift northward, ${ }^{74}$ per-

70. IPCC Adaptation Report, supra note 39, at 18 (footnotes omitted).

71. Easterling et al., supra note 38 .

72. Id. at 20 .

73. See id. 
haps not good news for Florida. Other areas where adaptation may be required include forestry, health hazards from heat stress, and conservation management. ${ }^{75}$

The Stern Report contains the most extensive discussion of adaptation costs. The Report estimates that

[i]nfrastructure is particularly vulnerable to heavier floods and storms, in part because OECD economies invest around $20 \%$ of GDP or roughly $\$ 5.5$ trillion in fixed capital each year, of which just over onequarter typically goes into construction $(\$ 1.5$ trillion - mostly for infrastructure and buildings). The additional costs of adapting this investment to a higherrisk future could be $\$ 15-150$ billion each year $(0.05-0.5 \%$ of GDP), with one-third of the costs borne by the US and one-fifth in Japan. This preliminary cost calculation assumes that adaptation requires extra investment of $1-10 \%$ to limit future damages from climate change. ${ }^{76}$

In Britain alone, one "study estimated that a cumulative increase in investment of $\$ 18-56$ million ( $\$ 10-30$ million) each and every year for the next 80 years would be required to prevent the costs of flood damages escalating in the UK."77 As an example of possible infrastructure needs, consider the risks to London:

Flooding would cause immense disruption to London's commercial activities, and could cause direct damage equivalent to around $£ 50$ billion (plus wider financial disruption). Climate change could increase the maintenance costs of flood defences in the Thames over 100 years from $£ 3.8$ billion without climate change ( $£ 1.1$ billion, Green Book discounted) to $£ 5.3-£ 6.8$ billion ( $£ 1.9$ - $£ 2.8$ billion, Green Book discounted) with climate change. . . . The design of the [Thames] Barrier allowed for sea level rise but did not make any specific allowance for changes in river flows or the height of North Sea storm surges. . .. After [2030], the risk increases, potentially reaching 1-in-50 years by the end of the century without

74. Id. at 21 .

75. Id. at 3 tbl.1.

76. STERN, supra note 27, at 473 (footnote omitted).

77. Id. 
any active intervention to upgrade capital defences. ${ }^{78}$

Stern also reports some very preliminary efforts regarding the cost of adaptation in the developing world:

The most recent estimates come from the World Bank that show the additional costs of adaptation alone as $\$ 4-37$ billion each year. This includes only the cost of adapting investments to protect them from climate-change risks, and it is important to remember that there will be major impacts that are sure to occur even with adaptation. The World Bank estimate is based on an examination of the current core flows of development finance, combined with very rough estimates of the proportion of those investments that is sensitive to climate risk and the additional cost to reduce that risk to account for climate change (5-20\% as a very rough estimate). ${ }^{79}$

Another estimate, covering only the least developed countries and the short term, is over a billion dollars for the most urgently needed adaptation measures. ${ }^{80}$

The cost of adaptation may or may not be large in comparison with the total world economy, but that comparison will not be relevant to localities that need billions of dollars worth of expenditures for climate change adaptation. One of the safer predictions about the impact of climate change is that the debate over who will bear those costs is likely to become quite heated.

\section{WhO SHOULD PAY?}

Either society will invest in adaptation, or the effects of climate change will be even worse than they need to be. We can all hope for the first of these alternatives. But to say that "society" will invest is to gloss over a key question: at the end of the day, who should bear the cost? To address that question, we must first consider the possible norms that might cover the choice of an allocation system and then examine the primary alternative allocation schemes in light of those norms.

78. Id. at 479 box 19.3 .

79. Id. at 502 (footnotes omitted).

80. Id. at 504 . 


\section{A. Applicable Norms}

The tort system-and by extension, other loss allocation schemes-has several goals. ${ }^{81}$ Probably the two most important goals are deterring harmful conduct (the efficiency or deterrence rationale) and corrective justice (restoring moral balance by rectifying harm). Loss distribution (which can be considered a way of providing insurance against social risks) is another goal, perhaps more important in social compensation schemes than in tort. ${ }^{82} \mathrm{~A}$ final set of goals is oriented towards maintaining societal cohesion-providing redress for social grievances or exhibiting social solidarity with victims. ${ }^{83}$

It is helpful to group the possible goals for a loss allocation system under four headings: behavioral effects, loss-spreading, concepts of just deserts, and distributive.

\section{Behavioral goals}

One goal of a loss allocation scheme is to deter the behavior that causes the losses. We would hope, for example, that medical malpractice liability causes doctors to be more careful or that toxic tort liability leads to fewer exposures to toxic substances. Clearly, we would like to provide an incentive to reduce emissions of greenhouse gases in the future, particularly to the extent that an effective regulatory scheme does not exist. This is a standard argument for adopting a prospective rule that imposes liability on harm-causing entities.

Less obviously, there may also be useful incentive effects created by the prospect of retrospective liability. It is obviously impossible to deter conduct that has already taken place. Nevertheless, establishing a rule that requires compensation for past emissions can provide a precedent for future liability schemes that cover other emerging environmental harm. For example, the fear that another country might emulate CERCLA (the Comprehensive Environmental Response Compensation and Liability Act) liability, which imposes retroactive liability on waste generators for clean-up costs at hazardous waste disposal sites, gives companies an incentive to be careful in disposing of hazardous wastes, even if

81. For discussion of these goals, see KENNETH S. ABRAHAM, THE FORMS AND FUNC. TIONS OF TORT LAW 14-20 (2d ed. 2002).

82. See id.

83. For an insightful discussion of this solidarity rationale in the context of catastrophic natural events, see Stephen D. Sugarman, Roles of Government in Compensating Disaster Victims, 10 ISSUES IN LEGAL SCHOLARSHIP 1 (2007), available at http://www.bepress. com/ils/iss 10/art1/. 
that country does not currently have a stringent regulatory scheme. Thus, the expectation of retroactive liability can provide useful incentives to avoid novel forms of harmful conduct. ${ }^{84}$ In the absence of such a liability threat, when new environmental issues arise, those producing the harms will assume that they have a free ride until a liability scheme that deals specifically with the new problem is put into effect. This would discourage early efforts to reduce harmful conduct.

Thus, a general policy of retroactive liability for environmental harm might have valuable deterrent effects. ${ }^{85}$ Moreover, serious discussion of retroactive loss allocation now could have an immediate deterrent effect on emitters who might otherwise resist reductions. As Louis Kaplow pointed out some twenty years ago in what still may be the leading economic analysis of retroactivity issues,

[s]ometimes new legal rules should be made fully retroactive: they should be applied to time periods before the enactment date, even as to investments no longer in existence. This sort of transition policy is hardly novel. For example, newly announced standards of common law liability are usually applied not merely to investments that continue in existence after the announcement date, even though undertaken earlier, but also to the effects of such actions that result prior to the announcement date.

The incentives analysis developed above favors precisely such retroactive application when the justi-

84. It is also arguable that the liability would not be truly retroactive. As the Restatement drafters note, "the abnormally dangerous doctrine has a significant application in the context of environmental harms," including application to activities such as toxic waste handling that are not at all uncommon in our economy. RESTATEMENT (THIRD) OF TORTS: LIABILITY FOR PHYSICAL HARM § 20, at 323-24 (Proposed Final Draft No. 1, 2005). Applying strict liability to production of greenhouse gases arguably could be justified on this basis or on the basis of public nuisance law. See Kenneth P. Alex, California's Global Warming Lawsuit: The Case for Damages, in Clikfford Rechtschaffen and Denise Antolini, Creative Common Law Strategies for Protecting the Environment (2007). Actually collecting in court may not be feasible because of problems of proof, but nevertheless the legal duty of emitters to avoid harm to the public may already exist.

85. This deterrence rationale has some inherent limitations. The deterrence rationale clearly does not apply before the point when the harmful nature of the conduct could reasonably have been discovered, and it applies with greatest force to activities whose harmful nature has already become clear. Moreover, once an effective regulatory scheme is in place, liability for further emissions may not serve a useful deterrent function, assuming that the regulatory scheme is optimal. But potential liability may provide useful incentives in the period between the discovery of the harmful environmental effect and the implementation of an appropriate regulatory scheme, or as a backup incentive if the regulatory scheme is too weak. 
fication for a reform suggests that the prior activity was undesirable. For example, when the government bans a product on the basis of recently completed studies indicating that the product had always been harmful, penalties should also be applied to production prior to the date of the announcement; failure to do so would decrease the incentives for manufacturers to take such risks into account ex ante. By contrast, if a new rule were established in response to a change in circumstances, the same reasoning would not support such retroactive application. ${ }^{86}$

A loss allocation scheme can also affect the behavior of those who experience the losses. If those suffering harm are risk averse, a compensation scheme can encourage them to engage in socially desirable behavior by providing a kind of insurance against losses. But loss compensation can also encourage behavior that actually adds to the total losses, a form of moral hazard. A classic example is that fire insurance can cause a reduction in precautions against fire. Similarly, the availability of flood insurance may encourage individuals to build in vulnerable areas if the premiums do not fully reflect the risk. Or, expecting that flood control will be provided, individuals may move into vulnerable areas, forcing the government to invest in flood control that would not otherwise be necessary. And since no flood control system is perfect, the end result may be that more people are in harm's way when the system is overloaded or fails for other reasons.

Related to moral hazard is the issue of rent-seeking. Individuals who might benefit from adaptation measures may pressure the government into investing in mitigation if the cost falls on someone else. Thus, the government might be lead to over-invest in adaptation projects that are socially wasteful or at least lower priorities than other possible government expenditures. For example, if the government pays for all flood control projects, local residents will have an incentive to lobby for projects where the benefits to them are outweighed by their costs-a classic form of pork barrel politics. ${ }^{87}$

In addition to its direct effects on economic behavior, any system of loss allocation will involve transaction effects. In some circumstances, the process of reallocating losses may itself have so-

86. Louis Kaplow, An Economic Analysis of Legal Transitions, 99 HaRv. L. REV. 509, 551-52 (1986) (footnote omitted).

87. Of course, as the Katrina disaster in New Orleans shows, failure to invest in appropriate flood control can also be a terrible mistake. 
cial benefits. It may lead to the production of additional useful information, such as a better accounting of the harms caused by climate change or fuller information about which forms of adaptation are desirable. Or the process may provide a sense of fair treatment to those who experience losses. On the other hand, in general, we would prefer to keep transaction costs as low as possible so that social resources are not absorbed by the operation of the loss allocation system. In the extreme case, implementing a loss allocation system might cost society as much as the losses themselves, which is obviously undesirable.

Thus, an ideal loss allocation system would have four behavioral effects. It would induce optimal mitigation of greenhouse gases. At the same time, it would provide a disincentive to inefficient adaptive behavior. It would also counter any behavioral distortions caused by risk aversion among those experiencing losses. Finally, it would minimize the incentive to invest social resources in the operation of the system itself, except where the process results in some socially desirable product other than the loss allocation itself.

\section{Loss-spreading}

In general, risk averse individuals would prefer a known cost (say, in the form of insurance premiums) to an uncertain loss, even if the expected value of that uncertain loss is greater than the cost of the premiums. The insurance function is probably strongest for the harms caused by extreme weather events such as hurricanes, where the victims' identity is inherently unpredictable. The case for insurance is weaker when harms are more predictable, such as the impact of gradual sea level changes on coastal areas. When harms are completely predictable, however, insurance has no role: everyone who would buy a policy would also collect for the loss, providing no room for loss spreading.

Even when losses are predictable and hence non-insurable, society may have an interest in loss-spreading. Those who come out on the losing side may be a source of social instability if they feel their losses are unfair. Thus, loss-spreading may help to keep social peace. In addition, loss-spreading may represent a form of solidarity toward fellow citizens. We may feel that, even if they are purely the victims of bad luck rather than any culpable activity by the rest of us, we have some duty to assist them. We might envision a kind of social compact in which fellow citizens have undertaken a mutual duty of assistance in the face of mishaps. Such an understanding may underlie our willingness to invest in emer- 
gency help for individuals who are stranded in the wilderness or are victimized by natural disasters, even when the expense is far in excess of what we would have paid to prevent the harm in the first place.

Within the United States, there is some argument for expressing solidarity with fellow citizens who are suffering distinct harm because of widespread national practices. Watching the television coverage of Hurricane Katrina, many Americans must have felt a pang that they would not have felt if the event had occurred elsewhere in the world. But for some, a similar sense of solidarity may extend more globally.

The potential social conflicts resulting from climate change also need to be considered. Individuals who suffer loss or displacement due to climate change are likely to be angry and resentful. This effect could be potentially destabilizing in some parts of the world, posing potential threats to international and U.S. security. If the United States is identified as the cause of massive floods or droughts, we can expect the resulting anger to be reflected in increased terrorist threats, potential disruptions to our supply of natural resources, and other harms. Within the United States, effects are likely to be more muted but could still lead to political animosities and polarization. The fact that some states have already filed suit against emitters located elsewhere is an indication of the kind of legal and political demands for compensation that may be made.

\section{Just Deserts}

Corrective justice involves complex moral issues which are not likely to be resolved simply or to everyone's satisfaction. 88 Emissions of greenhouse gases were not made with the intent to cause harm to others. How culpable was this conduct? At the very least, it seems arguable that, at some point, failure to take reasonable precautionary measures to reduce emissions became negligent. Given the amount of misinformation that has been spread by industry-sponsored groups, as well as possible efforts within the United States government in the past six years to suppress information, ${ }^{89}$ there is also the possibility of deliberate misrepresenta-

88. Matt Adler's analysis suggests that the climate change situation may be an imperfect fit with philosophical theories of corrective justice, although it appears that the philosophical case for compensation at the international level seems stronger than at the local level. Matthew D. Adler, Corrective Justice and Liability for Global Warming, 155 U. PA. L. REv. 1859 (2007).

89. For a discussion of the Bush Administration's unprecedented efforts to prevent disclosure of scientific conclusions at odds with its policies, see Robert F. Rich and Kelly R. 
tions, as turned out to be the case in the tobacco industry regarding the risk of cigarettes. ${ }^{90}$

The concept of unjust enrichment is another form of just deserts. We might well think that those who have in some sense profited from a situation have some duty to recompense those who have lost out at their expense, particularly when those who have profited have been the cause of the loss. The law of restitution is built around this concept.

The idea of just deserts might also lead us to counter the role of luck with social outcomes. We might think that an individual's welfare should depend on morally relevant facts like effort or moral behavior, rather than on the happenstance of being born with particular genes or living in an area that has the bad luck of being affected by climate change.

If our only goal is social welfare, then just deserts is just a distraction that invites us to look at the past and present when we should be planning for the future. But for many, just deserts has a moral appeal independent of its impact on future welfare. We may feel that the victims of wrongdoing should be compensated by those who are at fault, even if there is no reason to think this will improve the overall welfare of society or provide useful incentives. Not everyone shares this view of social justice, but for those who take this position, just deserts will be an important factor in designing an allocation system.

\section{Distributive and Social Goals}

In formulating any social policy, we may also be influenced by how it effects the distribution of income and wealth, and in particular by whether it hurts or harms the poor. In terms of climate change, the income distribution issue is strongest at the interna-

Merrick, Use and Misuse of Science: Global Climate Change and the Bush Administration, 14 VA. J. SoC. POL'Y \& L. 223 (2007).

90. At this point, it is impossible to know whether there was a deliberate campaign of deception, but pre-trial discovery in one of the nuisance cases or intensive congressional hearings might shed light on the subject. Given the amount of money to be gained in some industries by forestalling any serious response to climate change, it would not be surprising to learn of deliberate deception of the public or improper pressures on governments. Consider, for example, a petroleum institute memo about a campaign to indoctrinate science students and teachers about the alleged uncertainties of climate research in order to impede efforts such as Kyoto. See Laurie David, Science a la Joe Camel: An Inconvenient Truth About One American Teachers Association, SAN Francisco CHRON., Dec. 10, 2006, at C4. Notably, that teachers' association declined to distribute copies of Al Gore's An Inconvenient Truth because it considered the film to be "political" and because doing so might imperil the association's capital campaign. Perhaps coincidentally, ExxonMobil had been a strong supporter of the association. Id. 
tional level, where affluent nations like the United States figure heavily as emitters, and victims are sometimes poorer countries such as Bangladesh. Mitigation responsibilities in international agreements seem to vary inversely with per capita income, which provides some indication of an international consensus in favor of lessening the burden on poorer countries.91

As the Stern Report says,

[t] he poorest in society are likely to have the least capacity to adapt .... Given that the greatest need for adaptation will be in low-income countries, overcoming financial constraints is also a key objective. This will involve transfers from rich countries to poor countries. The argument is strongly reinforced by the historical responsibility of rich countries for the bulk of accumulated stocks of GHGs. Poor countries are suffering and will suffer from climate change generated in the past by consumption and growth in rich countries. ${ }^{92}$

Similarly, the head of an IPCC panel recently said, "[i]t's the poorest of the poor in the world, and this includes poor people even in prosperous societies, who are going to be the worst hit."93

Within the United States, distributive effects may be more muted. For instance, some coastal areas, like Louisiana, are relatively poor; others, like California, are relatively affluent. Those who live directly on the coast may be impoverished swamp dwellers or glamorous movie stars. Without sophisticated study of the incidence of climate change generally-and adaptation needs particularly-on different social groups, wealth effects are difficult to ascertain. It does seem clear, however, that some effects of climate change, like heat wave deaths, will fall more heavily on the poor even in the United States, and adaptation measures geared to these effects are a possible target for redistributive policy.

91. See Jeffrey A. Frankel, The Brookings InSt., Pol'y Brief No. 52, Green. HOUSE GAS EMISSIONS 4 (1999), available at http:/www.brookings.edu/papers/06energy_ frankel.aspx (reporting that a $1 \%$ increase in per capita income implies a $0.1 \%$ greater sacrifice).

92. STERN, supra note 27 , at 42 .

93. Kanter \& Revkin supra note 16 (internal quotations omitted). 


\section{B. Four Possible Principles}

This Article considers four basic principles that we might adopt to allocate the cost of adaptation. The cost of an adaptation measure could be placed on the beneficiaries of that adaptation measure, on the public (for example, taxpayers), on emitters of greenhouse gases, or on groups that receive net benefits from climate change. Each of the four contains a host of sub-alternatives-for example, the idea that the taxpayers should bear the bill has as many variations as there are possible methods of taxation. Moreover, there is no reason to think that the list of four basic alternatives is exhaustive. Still, considering these four is at least a good starting point.

\section{Principle 1: Beneficiaries Pay.}

Normally, people have to pay for goods and services if they want to consume them-at least, this is the theory of a market economy. When the private market is unable to produce certain goods, perhaps because of collective action problems, the government steps in. But, the basic principle that the costs of producing goods should be borne by those who benefit from them remains appealing. On this theory, the individuals who benefit from adaptation should pay the cost. On an analogous issue in the theory of taxation, Eric Rakowski suggests that

[p]eople who live in far-flung areas present an interesting problem if in fact their personal security is more costly to preserve, given a nation's geography and its neighbors. Local differences in risks and associated police costs are in many nations reflected appropriately in varying local taxes. . . Perhaps the way to think of these situations is the following. A nation committed to protecting its citizens as equals will attempt to maintain its borders and to supply people living throughout its territory with basic protection. But it cannot fully equalize protections throughout, at least not if it taxes all the same, so that those who choose to live in certain places know that they take on some risks and costs, perhaps including private protection, as the price of their decisions. Privately purchased protection or the assumption of additional risk, coupled with equal taxes, is tantamount to equal protection with un- 
equal tax payments. ${ }^{94}$

In simpler terms, the point is that people who choose to live in riskier areas cannot fairly demand that their fellow citizens pay to provide them protection from these risks.

This principle could be implemented in several different ways. It would seem to call for placing the responsibility for adaptation at the lowest possible governmental level so that both costs and benefits would be concentrated on the same group. Thus, coastal measures might be financed by coastal states, or even better, by coastal counties within those states. Sometimes, an adaptation project's beneficiaries will not correspond to any existing political entity. We might respond by creating a special purpose entity; it is easy to imagine Climate Change Adaptation Districts like today's drainage or irrigation districts.

Alternatively, we might finance adaptation projects through special tax assessments, just as the owners of property may have to pay a special assessment to finance sidewalks or other improvements. For instance, if new varieties of wheat are needed because of climate change, wheat farmers might pay a special fee. Or, if a flood zone needs additional levees, landowners might pay a special tax.

In terms of the social goals discussed elsewhere, "Beneficiary Pays" rates particularly well in terms of eliminating moral hazard and rent-seeking. If project beneficiaries have to pay for projects, they are unlikely to want to over-invest beyond the project's benefits or to lobby the government for projects that will raise their taxes more than any corresponding benefit they receive. To the extent that we are concerned about overinvestment in adaptation, "Beneficiary Pays" is the ideal solution.

On the other hand, "Beneficiary Pays" does not advance other possible social goals. For example, it provides no incentive for emitters to mitigate. It leaves the costs of climate change where it finds them, doing nothing to advance loss spreading. Furthermore, to the extent that we view emitters as culpable or unjustly enriched by their failure to mitigate, "Beneficiary Pays" does not advance the concept of just deserts. Finally, because benefits and costs fall on the same individuals, "Beneficiary Pays" also fails to serve any redistributive goal.

Whether or not these are serious shortcomings depends in part upon whether these other social goals are viewed as important. It

94. Eric Rakowski, Can Wealth Taxes be Justified?, 53 TAX L. REV. 263, 304 n.75 (2000). 
also depends on whether we have alternative methods to advance those goals. For example, if we have optimum mitigation requirements, complete insurance for all risks, and a fiscal system that achieves our desired income distribution, we do not need to rely on the loss allocation system to achieve those goals. We may also think that just deserts is not a valid goal for social policy or that the circumstances of climate change are not such as to involve any principle of just deserts. Thus, evaluating the normative appeal of "Beneficiaries Pay" may be complicated.

There are also practical issues to be considered. Determining the beneficiaries of a given project may be straightforward, thus limiting transaction costs. Yet this will not always be true. Adaptation projects may indirectly benefit other sectors of society. For example, a water storage project may primarily benefit users in the immediate area, but it may also offer a potential fallback supply to other users in unusual drought conditions. Or, it may prevent local residents from moving elsewhere, which would have created the need for public services and infrastructure in those locations. Disputes over how benefits are allocated could become quite heated, with expert witnesses marshalling the evidence for attributing benefits in different ways.

In short, "Beneficiary Pays" is most appealing when the beneficiaries can be easily identified and when mitigation incentives, loss spreading, and just deserts are seen as unimportant or not relevant, or these other goals are addressed through other mechanisms.

\section{Principle 2: The Public Pays.}

Another alternative is for the cost of adaptation to fall on the federal taxpayer. ${ }^{95}$ (In the international system, presumably the cost would fall on individual nations in proportion to wealth or income, with the burden transferred to individuals through national tax systems). This system achieves the maximum amount of loss spreading. It expresses the idea that climate change is a national

95. For present purposes, it is irrelevant whether the government finances projects directly through taxes or by issuing bonds, which will later result in payments financed through taxes. It would make a difference, however, if imperfections in the bond market allowed the government to transfer some of the costs away from taxpayers to bondholders. This might have different loss-spreading and distributional effects than taxation, depending on the identity of the taxpayers. For example, if the federal government sold all of the bonds to foreigners and then defaulted, the taxpayers might escape any financial responsibility (though the government's credit might be impaired). On the other hand, if the government did not default, then adaptation costs would be pushed later in time, to fall on the shoulders of later taxpayers when the bonds are paid off. 
problem, thus emphasizing national solidarity in the face of the threat. To the extent we are satisfied with the tax system in distributional terms, it also provides the correct distributional result for climate costs.

We can imagine several ways for this principle to be implemented. The federal government might simply take mitigation as its own responsibility and pay for projects directly from the Treasury. Alternatively, state and local governments might receive federal grants to engage in mitigation, or private sector actors might receive tax credits or other subsidies.

Although it rates well in terms of loss spreading, "Public Pays" is problematic along other dimensions. It maximizes the potential for moral hazard and rent seeking, since financial responsibility for adaptation is uncoupled from receipt of benefits. In the worst case scenario, climate adaptation might become the biggest pork barrel in history. It also allows emitters to escape any responsibility, which might be troubling in terms of just deserts.

One clear advantage of "Public Pays" is low transaction costs. Running the federal tax system is not cost free, but it is clearly much cheaper than other loss allocation methods such as litigation. The transaction costs would all be on the other side, in terms of identifying and implementing adaptation projects. But those costs are essentially unavoidable parts of any adaptation strategy, and there is no obvious reason why the costs would be higher if the federal government controlled adaptation than if the task were given to states or other entities.

Thus, "Public Pays" is most appealing when the need for adaptation is easily monitored (reducing the incentive to seek rent), when there is little risk that adaptation will cause undesirable reductions in self-protective action by beneficiaries, and when just deserts and mitigation incentives are not pressing concerns.

\section{Principle 3: The Polluter Pays.}

The strongest justification for the third possible approach, "Polluter Pays," is just deserts. Prior to the last quarter of the twentieth century, emitters may not have had strong grounds for believing that their conduct would cause serious harm. Nevertheless, the fact remains that they have caused harm, and in the process, they have enjoyed lower costs than they would have incurred by using alternative technologies or by reducing output. Thus, there is arguably a strong element of unjust enrichment, at least in some situations. For those concerned with culpability, apportioning responsibility on the basis of emissions after some cutoff date would 
be an appropriate response. One possible cutoff date would be 1992, when the United States and other nations entered into a framework agreement to reduce greenhouse gases. ${ }^{96}$ At that point, the international community had formally identified the harm; any emitter after that date was at least on notice of the damaging nature of the conduct. Thus, there is a potentially plausible basis for reallocating adaptation costs to emitters.

In addition to just deserts, "Emitters Pay" could serve other social goals. As discussed earlier, the prospect of financial responsibility could serve as a valuable incentive for reducing emissions. This is especially relevant in the absence of a global system of emission mitigation. Furthermore, if climate changes victims are poorer than emitters, as seems to be true at least in the international sphere, "Emitters Pay" could also serve redistributive goals. Finally, emitters may be in a good position to spread costs to shareholders or consumers, thus serving the loss-spreading function.

Some concrete proposals have made for implementing the "Emitters Pay" principle internationally:

Some commentators have proposed the use of adaptation levies. In particular, they suggest an air ticket levy may be particularly relevant given the low levels/exemptions from taxation from which it has benefited historically, and the projected growth in aviations emissions. Such a levy could distinguish between short- and long-haul flights and classes of travel, and could be argued to have advantages on grounds of both equity (taxing "luxury" emissions rather than "survival" emissions) and efficiency (using a price instrument rather than quantity). ${ }^{97}$

Another suggestion is that "a new levy on Annex 1 countries, set at a fixed percentage of GDP and allocated to adaptation, would be one way to give a clear funding commitment under the UNFCCC."98

The United States and other countries have already agreed in principle to take some responsibility for adaptation measures in less developed countries. Article 4.4 of the United Nations

96. See Brown, supra note 19 , at 10742 .

97. STERN, supra note 27 , at 628 box 26.2 (footnotes omitted).

98. Id. 
Framework Convention on Climate Change states that "developed country Parties and other developed Parties included in Annex II shall also assist the developing country Parties that are particularly vulnerable to the adverse effects of climate change in meeting costs of adaptation to those adverse effects." 99 Article 4.1(e) also calls on countries to "[c]ooperate in preparing for adaptation to the impacts of climate change;" countries are additionally directed to "develop and elaborate appropriate and integrated plans for coastal zone management, water resources and agriculture, and for the protection and rehabilitation of areas, particularly in Africa, affected by drought and desertification, as well as floods."100 This cooperation mandate amounts to a requirement of in-kind contribution to adaptation measures. Thus, at least in principle, the United States and other signatories to the framework agreement seem to have already agreed to assist with adaptation at the international level. It is also worth noting that the parties to the Kyoto agreement have embraced the use of an adaptation fund which is financed by a share of the proceeds generated by the Clean Development Mechanism. ${ }^{101}$

Among emitters, adaptation costs could be allocated on the basis of pro rata contributions to emissions. ${ }^{102}$ An alternative starting point for assessing responsibility for climate change liability is suggested by the penalty provisions of the Clean Air Act (CAA). Under section 120 (d) of the CAA, polluters are assessed a penalty for noncompliance with the statute based on "the economic value of noncompliance."103 By removing this economic benefit, the noncompliance penalty eliminates the incentive to delay compliance and also prevents firms from obtaining an unfair advantage over competitors who have chosen to comply promptly. By analogy, entities that have failed to take timely steps to reduce greenhouse emissions could be assessed on the basis of the economic benefits that they have attained from the delay. This would have an incentive effect by reducing the benefits of delay, but could also be justified as a form of restitution for unjustly gained benefits.

"Emitters Pay" could be implemented through some kind of

99. U.N. Framework Convention on Climate Change art. 4.4, http://unfccc.int/ essential_background/convention/background/items/1362.php. (last visited Dec. 3, 2007).

100. Id. art. 4.1(e).

101. Dean Scott, U.N. Climate Talks Make Some Progress on Adaptation, Joint Implementation, 29 INT'L ENVTL. REP. 867 (2006).

102. Allocation issues are discussed in detail in the third of my articles, Farber, Who's to Blame?, supra note 1.

103. 42 U.S.C. $\$ 7420$ (a)(2)(A) (2000). Regulations implementing this provision were upheld in Duquesne Light Co. v. EPA, 698 F.2d 456 (D.C. Cir. 1983). 
penalty or tax, or, alternatively, through a claims adjudication program or through litigation. ${ }^{104}$ The transaction costs are a genuine concern but may be manageable through good tax design or a well-crafted administrative compensation system. A key issue on which reasonable people may differ is whether emitters have some moral responsibility for the resulting adaptation costs. As compared with "Beneficiaries Pay" (but not the other principles), "Emitters Pay" also raises moral hazard and rent-seeking issues to the extent that the system is unable to weed out claims based on excessive adaptation efforts. One way to discourage this form of moral hazard is to emulate insurance companies and create a "deductible" that places some of the cost of any adaptation effort on the claimant. ${ }^{105}$

Short-term implementation of "Emitters Pay" seems relatively feasible, but there are additional problems posed by longer term use of this principle. As the relative shares of greenhouse emitters shifts over time, the ideal approach would be to establish how much of a source's emissions are in the atmosphere at any given time and then to determine the marginal change on temperature, finally tracing the marginal effects of specific weather phenomenon and, from there, deriving the marginal increase in adaptation costs. This may well be too complex for reasonable implementation. There is at least a prima facie argument for using average shares instead of looking to marginal effects. Also, over time, many emitters may disappear through bankruptcy, some form of business reorganization, or perhaps a regime change. This poses the problem of how to deal with these "orphan" shares.

Finally, because greenhouse gases remain in the atmosphere so long, today's emitters could be causing adverse impacts and hence adding to the costs of adaptations many years in the future. ${ }^{106}$ This could result in vastly long-term exposure to liability. A rough approximation might be simply to hold all current emitters liable for current adaptation costs based on their proportional share of current adaptation efforts, but to cut off future liability for those

104. Implementation mechanisms are discussed inFarber, Basic Compensation for Victims of Climate Change, supra note 1.

105. A similar technique could be adopted under "Public Pays" by requiring adaptation expenses to exceed a floor before they receive public support or by requiring cost sharing.

106. Some of the fluctuations can be seen from figures reported in Sunstein, supra note 24, at 39 fig.6. The United States was responsible for $23 \%$ of annual $\mathrm{CO} 2$ emissions in 1990 but will be down to $19 \%$ in 2025 , while China will go from $10 \%$ to $23 \%$ over the same time period. In terms of their share of cumulative emissions up to 2002, the United States will still be at $30 \%$, while China will be at only $8 \%$. This makes the question of whether to base contributions to adaptation costs on marginal emissions or on cumulative emissions quite important. I plan to explore this question in a separate paper. 
emissions. An alternative would be to require current emitters to pay into some kind of long-term adaptation fund, which could dispense funds for many decades as the adaptation needs arise. Assuming the fund can invest contributions in excess of current needs in the financial markets, discounting might allow the emitters to make current payments at some reasonable level.

\section{Principle 4: Climate Change Winners Pay}

Not everyone will be harmed by climate change, at least at moderate levels of temperature increase. "Winners Pay" postulates that those who benefit from climate change should help the losers adapt. This approach furthers loss-spreading and social solidarity goals. If we believe that luck is an inappropriate basis for distributing income and wealth, we might also support "Winners Pay" on the grounds of just deserts.

As Stern indicates, there will be some possible winners to whom this principle might apply:

In higher latitude regions, such as Canada, Russia and Scandinavia, climate change could bring net benefits up to 2 or $3^{\circ} \mathrm{C}$ through higher agricultural yields, lower winter mortality, lower heating requirements, and a potential boost to tourism. But these regions will also experience the most rapid rates of warming with serious consequences for biodiversity and local livelihoods. ${ }^{107}$

$\cdots$

[generally, the] broad distribution of impacts across many sectors might stimulate a broad northward shift in economic activity and population in regions such as [ ] North America or Europe, as southern regions begin to suffer disproportionate increases in risks to human health and extreme events, coupled with loss of competitiveness in agriculture and forestry, reduced water availability and rising energy costs. ${ }^{108}$

As a well-known journalist recently observed, the effects on property values could be remarkable in some locations. ${ }^{109}$ Cities

107. STERN, supra note 27 , at 138 .

108. Id. at 144 .

109. Gregg Easterbrook, Global Warming: Who Loses- and Who Wins?, 299 ATLANTIC $52(2007)$ 
like Buffalo, New York might find new popularity, while "Florida's rapid growth could be, well, swamped by an increase in its perilously high groundwater table," and "Houston could decline, made insufferable by worsened summertime humidity." 110 Internationally, "nearly all the added land-value benefits of a warming world might accrue to Alaska, Canada, Greenland, Russia, and Scandinavia;" 111 in particular, "[w]arming's benefits to Russia could exceed those to all other nations combined." 112 Real estate above the Arctic Circle may be a shrewd long-term investment!

"Winners Pay" has a number of drawbacks. It is prone to moral hazard and provides no incentives (or moral corrective) to emitters (except to the extent that winners might otherwise be tempted to increase emissions in order to promote additional climate change in their favor). Because the winner countries may have relatively low populations, it is a less than ideal way to engage in loss spreading, since only a small share of world population or even of the affluent will bear the costs. Nevertheless, this approach may have some appeal, at least as a secondary approach for loss allocation.

\section{Which Approach(es) to Favor?}

A table may be helpful in summarizing some of the main points of the discussion.

\begin{tabular}{|l|l|l|l|l|}
\hline & Beneficiaries Pay & Public Pays & Emitters Pay & Winners Pay \\
\hline $\begin{array}{l}\text { Incentives } \\
\text { for Emitters }\end{array}$ & No & No & Yes & No \\
\hline Moral Hazard & No & Yes & Yes & Yes \\
\hline Just Deserts & No & No & Yes & Possible \\
\hline $\begin{array}{l}\text { Loss Spreading } \\
\text { Distributive } \\
\text { Benefits }\end{array}$ & No & Yes & Partial & Partial \\
\hline
\end{tabular}

110. Id. at 56 .

111. Id.

112. Id. at 57. As Easterbrook puts it in somewhat lyrical terms:

And Russia! For generations poets have bemoaned this realm as cursed by enormous, foreboding, harsh Siberia. What if the region in question were instead enormous, temperate, inviting Siberia? Climate change could place Russia in possession of the largest new region of pristine, exploitable land since the sailing ships of Europe first spied the shores of what would be called North America. The snows of Siberia cover soils that have never been depleted by controlled agriculture. Id.

Easterbrook also advises the reader to "look for purchase opportunities near the waters of the Arctic Circle. . . . Assuming arctic ice continues to melt, the world's cargo vessels may begin sailing due north to shave thousands of miles off their trips." Id. at 60-62. 
My own preferred approach, at least tentatively, is "Emitters Pay." Clearly, some people have profited from the absence of greenhouse controls well after the need for such controls became clear. Their conduct will cause long-term harm to others. In order to provide redress to the victims and provide an incentive for care in dealing with other emerging environmental problems, compensation seems to be warranted. The argument for "Emitters Pay" seems to be strongest as applied to conduct taking place after the harms of climate change were identified, so that emitters were on notice, but before effective regulatory controls are in place, which reduces the deterrence argument. Perhaps the biggest challenge is transaction costs, which would probably choke any effort to use the litigation system to implement "Emitter Pays." There does, however, seem to be workable non-litigation approaches to implementing the principle. ${ }^{113}$

"Emitters Pay" may not be a feasible response because of political opposition or an inability to keep transaction costs manageable. It also seems most appropriate for the period of transitioning to an effective mitigation regime. An appealing fallback is "Beneficiaries Pay," which has the advantage of minimizing rent-seeking and moral hazard. "Public Pays" is rife with those problems but is better at spreading risk and handling redistribution. In practice, a mix between these systems may be best, with beneficiaries and taxpayers splitting costs. Whenever beneficiaries of adaptation are able to shift costs elsewhere, however, rent-seeking and moral hazard rear their ugly heads, and safeguards against these abuses need to be carefully considered.

"Winners Pay" seems like the weakest of the allocation principles, at least as the main basis for allocating adaptation costs. On balance, climate change will be harmful, which means that the winners will gain less than the losers will lose, making the win-

113. Here is one method for establishing such a system while keeping transaction costs under control. Consider a possible international compensation commission. The commission would receive claims from countries that have incurred adaptation expenses such as strengthening sea walls or providing alternative sources of ecosystem services to replace lost wetlands. The commission would determine which adaptation expenses were reasonable and would schedule them for compensation. Compensation might be directly from an international fund, but an alternative payment system might be more appealing if an international trading system for greenhouse gases was in place. In this alternative way of financing compensation, a set number of greenhouse gas allowances could be set aside for the commission. The commission would use these allowances to pay claims; in turn, the claimants could sell them to greenhouse gas emitters on the open market. The net effect would be that the sources doing the least to reduce their emission levels, which would have the greatest need to purchase additional emission permits, would indirectly provide compensation for the expenses of adaptation. Thus, a wealth transfer would take place from poorly controlled sources of greenhouse gases to the victims of climate change. 
nings a limited source of compensation. Moreover, the winners have merely been lucky, having drawn lucky numbers in the regional impact lottery; they have not been culpable in causing the problem. Thus, whatever appeal "Winners Pay" might have seems to be part of a general view that locational luck should not be a determinant of wealth. Accepting this principle would require massive international redistribution of a kind that does not seem to have much current traction; for example, oil revenues would have to be shared among the entire global population, and countries with good soil and climate would have to share agricultural earnings.

Even if we do not accept it as a separate principle, "Winners Pay" may be a byproduct of other approaches. In particular, "Winners Pay" may be a side effect of "Public Pays." If taxes are progressive (or even wealth-neutral), then the winners will end up with an increased share of the tax bill simply because of their increased wealth, while losers will see their taxes lowered. For example, a property tax would naturally increase as land values rise in areas with desirable climate changes and fall in other areas.

"Winners Pay" may not be appealing as a basis for legal cost allocation, but it may still have appeal as an ethical basis for voluntary financial contributions. If the semi-Arctic areas end up becoming wealthy because of climate change, then their inhabitants might well feel some moral imperative to help those who have been less fortunate. Such voluntary contributions are salutary, but I have doubts that the beneficiaries of climate change should be compelled to fund adaptation elsewhere except to the extent that they also bear responsibility for causing the situation or we adopt a general principle of global redistribution.

\section{CONCLUSION}

Given the high likelihood of climate change and the increasingly firm predictions of its impacts, it is only prudent to begin to consider how we will live with those consequences. This does not, of course, mean that we should merrily add greenhouse gases to the atmosphere in the hope that we will miraculously cope. But regardless of what mitigation measures are put in place, some degree of climate change-and hence some need for adaptation-will exist. This Article addresses the question of how the costs of adaptation should be allocated.

There is no completely uncontroversial answer to that question. Each solution has some normative appeal and some drawbacks. Without seeing a fully worked out version of the solutions, we are 
also at a disadvantage in considering their actual workability. More fundamentally, however, our choice may depend on how we resolve some basic moral questions, such as whether the emitters of greenhouse gas have a moral responsibility for the resulting damage.

We are likely to debate this problem for decades. This Article suggests, however, that there is at least a strong case to be made for shifting a share of adaptation costs to emitters. "Winners Pay," however, seems less appealing. Consequently, I would tentatively rank the principles in the following order of preference: first, "Emitters Pay"; second, a combination of "Public Pays" and "Beneficiaries Pay"; and third, "Winners Pay."

Getting greenhouse emissions under control is probably the highest priority, but we cannot delay for long in planning for adaptation. Climate change will affect infrastructure decisions that are being made all the time, such as how high levees should be or how much storage capacity to create for urban water supply. As these expenses begin to accumulate, we will have to start asking questions about who should pay. Indeed, it seems almost certain that there will be growing dispute over these issues, both within the United States and internationally. Although the solution suggested in this Article is only tentative, there can be no doubt about one point. The legal community needs to begin thinking hard about this question now, so we will be in a position to contribute to its resolution when it erupts onto the political agenda. 
HeinOnline -- 23 J. Land Use \& Envtl. L. 38 2007-2008 